\title{
The quarrel between populism and republicanism: Machiavelli and the antinomies of plebeian politics
}

\author{
Miguel Vatter \\ Department of Political Science, Universidad Diego Portales, Santiago, Chile.
}

\begin{abstract}
This article discusses the current debate between populist and republican accounts of democracy. To talk about democracy is inevitably to talk about the idea of a people and its power. From the beginnings of the Western political tradition, 'the people' has referred to both a constituted part of society (populus) and to a part excluded from political society (plebs). The article examines the differences between populism and republicanism in light of the different ways in which these two parts relate to each other, and the resulting conceptions of the power of the people. For populism, the people have power when the plebs achieves hegemony within the populus by wresting control of the state from the 'wealthy' elites. According to the alternative republican account developed in this article, instead, the people have power when the plebs inscribes within the state the possibility of abolishing relations of rule. The distinction between these two conceptions of popular power is pursued in terms of the opposing attitudes that populism and republicanism have in relation to the rule of law. The article also raises a hypothesis as to the historical reasons for these distinctions between populism and republicanism by examining three historical moments, which are crucial for the development of plebeian politics: the early Roman republic, the Augustinian foundation of a Christian republic and the crisis of guild republicanism in Machiavelli's age.
\end{abstract}

Contemporary Political Theory (2012) 11, 242-263. doi:10.1057/cpt.2011.25; published online 11 October 2011

Keywords: populism; republicanism; rule of law; plebeian politics; Machiavelli; Cicero

The revival of republican political theory has brought to the fore once again the importance of distinguishing between freedom as non-domination, which depends on the rule of law, and freedom as collective self-rule, which depends on a conception of popular sovereignty. For neo-Roman political theorists, popular sovereignty, being a species of sovereignty, is part and parcel of a theory of the state, whereas the rule of law - at least as it is conceived in the modern republican tradition - is not a mutation of state sovereignty

(C) 2012 Macmillan Publishers Ltd. 1470-8914 Contemporary Political Theory Vol. 11, 3, 242-263 www.palgrave-journals.com/cpt/ 
but represents a relatively independent sphere that limits state power. For this reason, Pettit argues that the ideal of a rule of law makes room for popular contestation of government policy but views with suspicion the Rousseauian claim that a people ought only to obey a law they have themselves participated in making, because such participation does not, by itself, exclude the possibility that the law is a medium of state domination (Pettit, 1997, 2009a, b).

Contemporary populist theory, for its part, is a variant of democratic theory in which the people gain control of the state in order to give their practice of self-legislation sufficient force to interfere with and modify both the system of rights, which is embodied by the rule of law, and the system of needs, which is embodied by the economy. For this reason, some theorists have criticized populism saying that it requires more republicanism (O'Donnell, 2007), and conversely other theorists have argued that the republican separation between the rule of law and democratic self-rule is averse to democracy and needs to be corrected by more populism (McCormick, 2006; Bellamy, 2007). A third variant has attempted to argue that the practice of constitution-making should be the first priority of populist politics (Kalyvas, 2009; Linera, 2009). The contemporary quarrel between republicanism and populism re-proposes the ancient and never pacified tension between the rule of the people and the rule of law.

To talk about democracy is inevitably to talk about the idea of a people and its power. From the beginnings of the Western political tradition, 'the people' has referred to both a constituted part of society (populus) and to a part excluded from political society (plebs) (Rancière, 1995a; Agamben, 2000). Accordingly, to settle the quarrel between republicanism and populism over the meaning of the power of the people one needs to give an account of how these two parts relate to each other. Machiavelli turns out to be a fundamental thinker for this task precisely because he is generally recognized as having attempted to formulate the republican task of the constitution of a free and equal people by means of a civil prince whose sovereignty is constructed in a state of exception to laws and is based on the conflict between plebs and nobles (Althusser, 2001). On the populist account, the people have power when the plebs achieves hegemony within the populus by wresting control of the state from the 'wealthy' elites (Laclau, 2005; McCormick, 2006, 2007). Thus, it is no coincidence that Laclau associates 'populist reason' with a systematic rethinking of Gramsci's theory of the 'New Prince', and McCormick names his form of populism a 'Machiavellian democracy' (McCormick, 2011). But did Machiavelli really think together the constitution of a people and the state of exception in such a populist manner?

In this article, I propose to read Machiavelli as offering a different way to articulate the part of the plebs with that of the 'people' such that it maintains the difference between state and rule of law emphasized by contemporary

C) 2012 Macmillan Publishers Ltd. 1470-8914 Contemporary Political Theory Vol. 11, 3, 242-263 243 
republicanism, while, at the same time, showing how this difference rests on another idea of class struggles that does not get recognized in populist theorization of social conflict. On this modified republican account, the plebs distinguish themselves from the populus because they struggle for a form of power that Arendt called 'no-rule' and which is exercised in the absence of the distinction between those who govern and those who are governed (Lefort, 1986a; Arendt, 1990; Vatter, 2005; Markell, 2006; Rosanvallon, 2006; Rancière, 2009; Abensour, 2010). From the populist perspective, the republican construal of the rule of law only serves to mask the conflict between elites and plebs. Populist political theory claims that the plebeian assertion of its equality with all the other parts of the populus necessarily takes an antinomian form because the plebs stand in a relation of exclusion with respect to the law. From the perspective of the modified, 'no-rule' republicanism I advance here, instead, the exclusion of the plebs from the rule of the populus, far from being the source of their impotence, is a condition that makes it possible for the plebs to act as a constituent power to make equal law. Machiavelli rescued this Roman republican perspective on the power of the people, and he showed how the rule of law ought to be understood as an essential component of plebeian politics.

Interpretations of Machiavelli have divided themselves between the camp of those who see him as a thinker of state order and the camp of those who see him as a thinker of the rule of law (Barthas, 2010). I propose to consider Machiavelli as a threshold figure who is helpful in thinking about democracy through the 'the antinomy of law and order' (Foucault, 2000, p. 417). This antinomy is different from the antinomy between plebs and rule of law established in populist political thinking because, in Foucault's antinomy, the plebs stand on the side of a political power to make law that rejects the pastoral power to govern and places the orders of the state in a 'state of exception'. In what follows, I begin by showing in what sense the contemporary populist conceptions of plebeian politics collapse the distinction between pastoral and political power. I then offer a brief genealogy of the idea of a 'people' intended to illustrate how the Christian idea of a republic in Augustine and then the humanist civic republican ideal contribute to the forgetting of the above antinomy, reducing the people to a function of state order. The article concludes with a reading of Machiavelli's recovery in Roman history of the plebeian struggle for no-rule as a struggle for the people's power to revolutionize the state and its orders in the name of equal law.

\section{Plebeian Equality from Lefort to Laclau}

The first contemporary political theory in which the division between people and plebs is tied to a republican conception of democracy is found in Lefort's 1968 
book on Machiavelli (Lefort, 1986a; Sfez, 1998; Flynn, 2006; Marchart, 2007). Taking up Machiavelli's central thesis of an opposition between that part of the people that 'desire neither to be commanded nor oppressed by the great' and the elites that 'desire to command and oppress the people' (Machiavelli, 1998, IX; Machiavelli, 1996, I, Chapter 5), Lefort postulates 'that political society exists only out of its division and is powerful only in so far as it can find in the effects of social division the possibility of relating to the external world' (Lefort, 1986a, p. 555). A democratic form of society affirms this internal division of the populus so that the place of rule becomes 'an empty place and those who exercise it [rule] as mere mortals who occupy it only temporarily or who could install themselves in it only by force or cunning' (Lefort, 1986a, pp. 303-304). For Lefort, a democracy upholds the difference between the 'ordered' populus and the 'savage' plebs so that the anarchic traits of the plebs may trouble the assignation of sovereignty to the people (Lefort, 1978, p. 44; Lefort, 1979, p. 23; Lefort, 1986a, pp. 303-304; Abensour, 1994; Nasstrom, 2007). Lefort contrasts this picture of a democratic society without sovereignty to a totalitarian form of society that denies the constitutive division of the populus and places at its foundation 'the representation of the People-as-One' (Lefort, 1986b, pp. 297-298). Before Rancière's, Badiou's and Negri's rejections of constituted politics on the grounds that it reduces the multiplicity of the 'masses' to the unity of the people, Lefort had already connected the condition of possibility of democracy with the 'uncountable' or 'savage' part of the plebs.

Departing from Gramsci's attempt to understand Machiavelli's 'new' or 'civil' prince as the constituent power of a radically democratic or communist society, Lefort no longer believes that it is possible for the plebs to become the state, to conquer hegemony in such a way as to give birth to a society without classes. He cannot think such a society 'without classes' otherwise than as an ideological illusion through which the civil prince, by means of 'simulation and dissimulation', attempts to master the paradox of a truly democratic political order, one that would be at once lawful and savage, by offering an image of a united and sovereign people that has 'successfully' integrated the radical difference of the plebs (Lefort, 1986a, pp. 411-417).

Instead, Lefort's interpretation of Machiavelli traces another trajectory for the constituent power of the people that bypasses the figure of the civil or constituent prince. In the Discourses on Livy, Machiavelli famously postulates that 'all the laws that are made in favor of freedom arise from their disunion [between the plebs and the great]' (Machiavelli, 1996, I, Chapter 4). Lefort understands this passage to mean that a constituent politics that emerges from the self-division of a people finds its authentic expression in the idea of the rule of law 'that keeps open the question of the unity of the state' (Lefort, 1986a, p. 477; 1992, p. 168). In order for the rule of law to extricate itself from the ideological machinery of the state and become a vehicle of a 
democratic constituent politics, the law must reflect the opposition of the plebeian desire for no-rule and the elites' desire for rule (Lefort, 1992, p. 175). Lefort oriented the understanding of republicanism towards the resistance of the 'savage' plebs to the state and the 'transcendence' of the law with respect to the orders of the state (Lefort, 1986a, p. 601), but he fell short of providing an account of how these two aspects fit together in Machiavelli. I show below that an inclusion of the plebs within the populus through the struggle for equal law and the extension of political rights occurs in and through a republican conception of the state of exception.

Post-Gramscian thinkers such as Negri, Laclau and Mouffe recover the sovereignty of the 'new' prince as an essential moment in the construction of a free people, while trying to avoid collapsing constituent plebeian politics into what Lefort identified as totalitarian politics. Where Laclau and Mouffe differ from Negri is in their conception of the Machiavellian 'civil' prince: for Negri, the 'civil' prince is that political agent that returns the state back into the social by democratizing and politicizing the living labour of workers and establishing an 'absolute' democracy without state (Negri, 1999; Kalyvas, 2000; Laclau and Mouffe, 2001; Vatter, 2007). Laclau's originality consists in the claim that the 'civil' prince is essentially a representative of the plebs, whose revolutionary action depends on functioning as a stand-in for the never fully realized ideal of a united, classless populus (Villacañas Berlanga, 2010).

The starting point of Laclau's populism remains the distinction between the people as constituted power (the people under political representation) or populus and the people as constituent power (the people as the uncountable part of those who have no part in the state) or plebs found in Rancière (1995a), but ultimately derived from Machiavelli's reading of the Roman republic, as transmitted by Lefort's interpretation. In that work, Rancière postulated that the excluded plebs or demos do not redress the injustice they have suffered by seeking recognition from the state as another one of its constituted parts, but by aspiring to change the entire polis, and by claiming that they stand for the whole populus (May, 2010). Laclau's innovation with respect to Rancière's formulation of the problem of the construction of a people consists in showing how the plebeian demand for justice gets interpreted by the 'civil' or hegemonic prince as the sovereign representative of the plebs. Laclau's 'populist reason' is an attempt to theorize the 'constituent', and no longer merely 'constituted', role that the prince or political representative plays in a democracy. Taking distance from the antinomian constructions of communism, such as the ones found in Badiou (2010) and Agamben (1993, 2007), Laclau argues that an account of how 'the represented depends on the representative for the constitution of his or her identity' (Laclau, 2005, p. 158) is absolutely essential to achieve what he calls the 'equivalential ruptures' that are constructive of a people 
and which transform liberal democratic politics into (authentically democratic) populist politics (Laclau, 2005, p. 93).

As Laclau explains, the identificatory function of the representative consists in turning the particular socio-economic demands of the plebs into political demands for universal equality by giving a name under which the plebs can become a people: 'the equivalential logic leads to singularity, and singularity to an identification of the unity of the group with the name of the leader. To some extent, we are in the situation comparable to that of Hobbes's sovereign' (Laclau, 2005, p. 100, emphasis mine). In short, 'populist reason' is the reason incarnated by the leader of the people: populism only exists as a Lenin-ism, a Mao-ism, a Peron-ism and so on.

Laclau's reference to Hobbes's notion of representation is not accidental, because his reconstruction of populism depends on a conception of a singular, sovereign representative who incarnates, so to speak, the equality of the plebs and the populus. Paradoxically, such a conception of the sovereign representative was already at work in Schmitt's and Voegelin's conceptions of political representation and reason of state. For Schmitt, in fact, Hobbes's theory of sovereignty is not a doctrine of monarchism, 'but has to be oriented towards political unity and its presence or representation' (Schmitt, 2008, p. 72). Schmitt believes that the problem of constructing the political unity of a multitude can be resolved only by reference to that representative of the people who is capable of providing an authoritative answer to the question of who is friend and who is enemy in a given society. For Schmitt, the Hobbesian sovereign is such a populist representative. Interestingly, Schmitt sees a continuity between Catholicism as political form (associated with Papal sovereignty) and Hobbes's Leviathan (associated with secular sovereignty): this continuity indicates the way in which pastoral power frames the terms of sovereign power.

That pastoral power is at stake in such a theory of representation becomes clearer in Voegelin's The New Science of Politics where representation is understood as 'the central problem of a theory of politics' (Voegelin, 1952, p. 1). This idea of representation turns on the principle that there must exist 'rulers who can act for the society, men whose acts are not imputed to their own persons but to the society as a whole' because they are bearers of a transcendent truth in the name of which they govern their people, as shepherds their flock (Voegelin, 1952, p. 37ff). Voegelin's crucial intuition is that without a representative who 'articulates' the totality of a people or populus to each of its members, that is, without a representative who allows society to represent itself to itself, this society or populus will not be able to select, in turn, its 'representatives' and thus will not be 'democratic'. Voegelin's fundamental principle for democracy is that 'articulation is the condition of representation' (Voegelin, 1952, p. 41): in this formula, 'representation' means democratic 
representation, representation 'from below', whereas 'articulation' means representation 'from above'. Voegelin turns the principle of democratic representation upside down, in a rather Hobbesian way, so that the representative becomes the effective constituent power, and this power, which should belong to the people, effectively becomes a constituted power.

Laclau's idea of 'populist reason' understood as the construction of the universality of the plebs by way of the 'articulation' of their differential demands into a series of equivalences, first, against an (internal) 'enemy', second, under the name of an 'empty signifier' of justice (Laclau, 2005, pp. 96-97), and, third, in the proper name of a leader, is strikingly similar to the late variant of reason of state coined by the Schmittian and Voegelinian theories of sovereignty. In both Schmitt and Voegelin, the public reason of the sovereign or leader accounts for the necessity to place 'common' laws in a state of exception for the sake of the higher welfare of the people, thus bringing together the pastoral and the sovereign models of power. But the origin of this notion of public reason as reason of state can be traced back - even before Hobbes - to the crisis of guild republicanism in the class conflicts of the late medieval and early modern society that shaped Machiavelli's political thought. In what follows, I briefly consider through which historical transitions the plebs passed from being a 'savage' and sovereign-less band of legislating outlaws to being a disciplined, militarized and ordered 'army' identified with its sovereign representative or leader and seeking to establish the ideal of a 'just' society on earth.

\section{How the Savage Plebs Became an Obedient Army: Christian and Civic Republican Conceptions of the People}

A classic illustration of the Foucaultian distinction between the political and the pastoral power of a people is found in Augustine's critical reinterpretation of Cicero's definition of a republic in the City of God. Cicero understood the republic as a function of the populus, which can be said to exist when there is 'an assembly of the multitude associated by a consensus of laws and by a community of interests' (cited in Augustine, 1984, 19, Chapter 21). This conception of the republic goes back to the Roman constitution at the time when the Struggle of Orders between the nobility and the plebs came nominally to an end with the lex Hortensia of $287 \mathrm{BC}$ that sealed the equivalence between the plebiscites of the plebs and the laws formulated under the auspices of the Senate. In that way, the plebs were reintegrated into the populus, and a 'common weal' was supposedly discovered to exist between the patricians and the plebeians (Magdelain, 1990; Mitchell, 1990; Cornell, 1995; Raaflaub, 2006). Cicero's formulation emphasizes a republican correlation between a people and

248 (C) 2012 Macmillan Publishers Ltd. 1470-8914 Contemporary Political Theory Vol. 11, 3, 242-263 
the consent that establishes something as law: a people is defined as all those who agree to stand under law, and whose agreement to the law is necessary, because they are sui iuris, independent. To be a part of the people is precisely to choose to serve the law in order not to depend on the guidance of some person or in order not to have any masters at all, as Cicero says in Pro Cluentio 146. In short, in this Roman tradition, the law carries an internal reference to the value of independence, or what Foucault calls 'mastery of self' (maitrise de soi sur soi) (Foucault, 2004, p. 187). The rule of law is what allows someone not to be governed.

Augustine changes this idea of law and makes the equality of the populus and the plebs depend on the result of the action of government or providence, as an achievement of what Foucault terms pastoral power. For Augustine, the nature of law no longer resides in the consensus it may encounter in a people, but in the fact that law becomes a function of the divine dispensation of justice, the right but not necessarily equal distribution of goods needed for the salvation and security of each and every individual of the flock: 'Where, therefore, there is no true justice there can be no law .... Further, justice is that virtue which distributes to everyone his due. Where, then, is the justice of man, when he deserts the true God and yields himself to impure demons? Is this to give everyone his due?' (Augustine, 1984, 19, Chapter 21). In Augustine, 'true justice' depends on the love of God, the ordo amoris or ordinate love of Creation that he opposes to the inordinate love of the 'world' or city of man (amor mundi) (Heykind, 2001; Gregory, 2008). Being governed by God's order becomes the condition of possibility of being directed to the common good and thus showing caritas or love of one's neighbour as oneself, 'and if this be lacking, there certainly is not a people ... for where there is no people, there is no republic' (Augustine, 1984, 19, Chapter 23). A true republic, therefore, requires a new understanding of a people as 'a community of a rational multitude which is associated by a communal concord of the things it loves' (Augustine, 1984, 19, Chapter 24). There are things that can be loved only together or conjointly, and loving these things is what makes a people, a well-ordered society, out of a multitude. The love of unity, or concord, rather than the equality of law, now lies at the basis of the equalization of the plebs with the populus.

Augustine's turn from law to justice, from discord to concord, as the constitutive feature of a populus is of critical importance in the history of the plebeian conception of politics because it is perhaps the first time that the plebs are conceived as what stands in need of being ordered, governed and ultimately saved: it signals the overturning of the Greek and Roman conception of the people as endowed with a legislating power of their own in favour of a conception of a united people at peace as a result of the pastoral care exercised by God through His earthly lieutenants. It is in an early treatise on divine providence that Augustine redefines the Roman populus - which in its original, 
archaic meaning refers to the king's army of citizen-soldiers - as an ecclesia (church) composed of faithful soldiers fighting against sin:

What else do friends strive for, but to be one? ... A people is a city for whom dissension is a danger. What else is to dissent but not to think alike [non unum sentire]? An army is made of many soldiers. And is not any multitude so much the less easily defeated in proportion as it is the more closely united? In fact, the joining is itself called a cuneus, a co-union, as it were [quasi couneus]. And what about every kind of love? Does it not wish to become one with what it is loving? (Heyking, 1999, pp. 562-564; Augustine, 2006, II, Chapter 18, Section 24) ${ }^{1}$

The exclusion of dissent is functional to the ordering of the multitude or plebs into the formation of a cuneus, the Roman military wedge-formation and attack column, which is to break open the opposing hordes of unbelievers. Augustine's conception of the plebs equalizes them with the populus as a function of their common love for the representative (Jesus as Christ) of the sovereign (God as Father and King). In the ideal of a Christian republic, the universal love of God is of one piece with the Christian love of the neighbour and the orderly pursuit of the common good. Christian love becomes the basis for the constitution of a people, whose members are now the dependent citizens, alieni iuris, of God's city, and whose principle of action has become obedience to divine providence or government, rather than the creation of human law.

There is a subterranean continuity between this Christian republicanism and the new way of equalizing the plebs with the populus achieved through the secularized leadership of the sovereign representative or Signoria in the fourteenth and fifteenth centuries. As Fubini and others have argued, during this period in the Italian city-states, the government (reggimento) of the Signoria begins to claim that it alone represents what Bruni and other civic humanists call the 'full, free, total and absolute power and authority of the entire Florentine people', bypassing the traditional communal, guild-based social forms of representation (Fubini, 1992, p. 226; Najemy, 2000). The Signoria's claim to represent the absolute power of the populus was prepared by a constant 'state of war ... inherent to the politics of territorial enlargement' that allowed 'a state of emergency [to] become, so to speak, the norm and conditioned internal politics, offering justification for institutional changes' (Fubini, 1992, p. 229). Unlike in Agamben (2003), here the state of emergency becomes the norm in conjunction with a shift in the conception of democratic representation: when the statutory councils of popolo and comune objected to such a government by emergency decrees, the members of the reggimento criticized the representatives of the councils with the argument that the latter 
merely represented the private or particular interests of the guilds, whereas the government itself represented the utilitates et salutes publicas (the interest and welfare of the entire people) (Fubini, 1992, p. 233). This top-down idea of popular representation proposed by the Florentine elites may well have been inspired by the arguments of legists and decretists who, during the twelfth and thirteenth centuries, worked towards establishing the sovereignty or superiority of the kingly estate (status regis) over all the other estates composing the political body because it is judged that such an office is of utility for all equally (publicae utilitatis) in a state of emergency (Post, 1964; Berman, 1983; Vatter, 2008). At this moment, the reason of Augustinian natural law, which follows the natural inclination of a people to love the order of divine creation, is replaced by the public reason of the sovereign representative of the people, who garners its legitimacy in and through the protection it affords to the 'natural' liberties of individuals, considered as standing apart from their communal and guild affiliations.

The nascent doctrine of sovereignty and state of exception that would emerge victorious with the reason of state developed by Bodin and Hobbes (Skinner, 1978; Rubinstein, 2004, pp. 99-130, 365-381; Nederman, 2009) spelled out the crisis of what Najemy has called the 'guild republicanism' of Italian city-states. Guild republicanism maintains the medieval sense of law as the 'constitution of a people' (constitutio populi): a 'natural' because uncoerced ordering of a people through guilds, each accorded a say in government according to their contribution to the satisfaction of social needs and according to long-held customs (Grossi, 2004). Despite its federalist appearance, in guild republicanism equality still remains a function of ordinate love, not of equal law: the common good or consensus between the different universitates or guilds, each pursuing the particular good of their brotherhoods, is achieved either on condition that a hierarchical ordering of these brotherhoods is accepted (natural law being the doctrine of this ordering), or on condition that a sovereign representative imposes a 'common good' over and above the interests of the guilds. Either way, guild republicanism falls prey to these two structuring possibilities of medieval political thought.

Machiavelli's political thought can be understood, in part, as offering a diagnosis of the failure of the guild model of republicanism and a willingness to move beyond both natural law and early forms of sovereign representativeness. When Machiavelli in the Discourses on Livy (I, Chapters 1-18) returns to the Struggle of Orders to show its constitutive function for republican freedom, it is no coincidence that he does so by rejecting the Augustinian conception of the political love of order and ordinate love. Machiavelli, in fact, divides the people's love into a desire to command or rule, and a desire not to obey or be commanded. This original 'perversity' of desire in the populus is part and parcel of his rejection of the idea of universal love (and with that the very idea 
of Christianity) as a principle for political order. In the Florentine Histories, Machiavelli uncovers the paradox that guild republicanism, despite constituting the populus on the basis of agreements between the interests of its social parts, fails to generate 'laws of freedom'. One of the central theses of the Florentine Histories is that the social conflict between 'the people who want to live according to the laws and the powerful who want to command them' (Machiavelli, 1988, II, Chapter 12), which was productive of laws of freedom in Rome, lost its legal productivity in Florence (Machiavelli, 1988, III, Chapter 1). Machiavelli identifies the problem in the fact that the organization into guilds places political conflict in the service of the struggle for economic advantage of one part of the city over another, thus reducing Florence 'from inequality to a wonderful equality', as he says ironically, eliminating all 'virtue in arms and generosity of spirit' (Machiavelli, 1988, III, Chapter 1) and giving rise to 'avarice' and the pursuit of 'contemptible honors' (Machiavelli, 1988, III, Chapter 5) under the protection of the new civil princes.

McCormick (2011) argues that Machiavelli's solution for the crisis of guild republicanism entails that the plebs engage in a more 'ferocious' and violent class-based struggle for political hegemony. Indeed, Machiavelli's analysis of the revolt of the Ciompi (Machiavelli, 1988, III, Chapter 12) and in particular the revolutionary speech of the representative of the plebeian part (infima plebe), with its attack on the guild system, has often been interpreted as relying on such an economic understanding of class conflict (Bock, 1990, p. 193ff; Zancarini, 2004). In my opinion, the interpretation that reduces plebeian politics to a matter of economic equalization fails to do justice to the point that Machiavelli rehearses throughout both the Discourses on Livy (I, Chapter 5) and the Florentine Histories (IV, Chapter 14), namely, that the reason why political conflict in Florence did not lead to equal law, as in Rome, but only to sectarian violence is due to the fact that political dissent became a means to achieve the goal of the redistribution of wealth. This economic objective occluded the real division within a populus between those who desire to rule and those who desire for no-rule. Machiavelli understood that the interests of the guilds were necessarily always particular interests, and that this divided the people into 'sects' that lost sight of a generalizable interest in not being ruled (Machiavelli, 1988, III, Chapter 5). Properly interpreted, the speech of the Ciompo shows that it is the interest in not being ruled that lies at the basis of the revolutionary demand to become a constituent power, to become 'princes of all the city', through a struggle against 'the avarice of your superiors and the injustice of your magistrates' (Machiavelli, 1988, III, Chapter 13). In the next section, I offer an interpretation of the Roman understanding of plebeian politics for which equal law and not equal wealth is paramount. I claim that Machiavelli recovers this understanding in the Discourses and writes it into the revolutionary speech of the Ciompo, which explains why the speech closes with

252 (C) 2012 Macmillan Publishers Ltd. 1470-8914 Contemporary Political Theory Vol. 11, 3, 242-263 
a very Roman appeal to the 'virtue in arms' and love of 'honor' of the plebs themselves (not of the nobles), the very qualities that Machiavelli claims were lost through the guild system. This appeal only makes sense in light of the fact that the social struggle posits a political-legal (not an economical) end of the struggle, namely, the recognition of the plebs as the 'strongest part' of the populus, which, according to Marsilius's famous formulation in the Defensor pacis, is the sole legitimate human lawmaker.

\section{The Plebeian State of Exception and the Struggle for Equal Law}

How was it possible for Machiavelli's republicanism to break through the double bind of Christian natural law and of representative sovereignty that destroyed guild republicanism? Machiavelli seeks to bypass both discourses of the constitution of a people by appealing to the verità effettuale of the Roman experience with plebeian politics. Machiavelli develops a model of Roman politics expressing an ideal of the vivere politico (not reducible to the humanist vivere civile), which brings together social conflict, state of exception and equality under law in a new revolutionary constellation. Similar to what Augustine did in The City of God, Machiavelli also starts from Cicero's definition of the republic as a function of the populus, but he chooses to date the beginning of the republic with the Struggle of Orders, rather than with its end. The question of where the continuity between Ciceronian and Machiavellian republicanism lies has been recently much debated (Skinner, 2002; Nederman, 2004; Connolly, 2007; Hankins, 2010). But one aspect of Cicero's political thought that appears close to a 'Machiavellian' discourse has not attracted much attention. If one returns to Augustine's discussion of Cicero's definition of the people, there is one point with which he agrees with Cicero, namely, when the Roman philosopher moves outside of the customary Roman understanding of the relation between people and law in order to connect, in a Platonizing manner, the idea of law (ius) to that of justice (iustitia) (Augustine, 1984, 19, Chapter 21). What Augustine likes about Cicero's gesture is that the reference to justice entails a reference to natural law. Cicero, in fact, argues that 'all human laws' have as their standard a 'primal, everlasting, and immutable law which is divine or natural reason' and that the distinction between just and unjust is due to nature (Wirszubski, 1950, p. 83; Cicero, De Leg. II, 8-9, 13; II, 1; I, 28; De Rep. III, 3). The reference to nature as the ground of legitimate law must be understood in opposition to another, plebeian standard of law-making, namely the desire for equal freedom under law (aequum ius). Equal law had been the principle of the plebeian struggle against the nobility and their inherited or natural dignitas, their 'natural or divine right' to command. As Wirszubski points out, Cicero develops his 
discourse on natural law precisely because he is unwilling to grant the people an ultimate power to make or change laws, that is, to grant them a constituent power (Wirszubski, 1950, pp. 83-85).

At stake in these two understandings of law-making are two conceptions of the state of exception. For Cicero's appeal to natural law not only served the ultimate purpose of providing the Roman constitution with a moral foundation, as Wirszubski claims, but was also part of Cicero's effort to legitimate the Senatus Ultimum Consultum, a patrician prerogative to take exception to the statutes established by the popular assemblies, and which Agamben has identified as one of the roots of the idea of the state of exception (Agamben, 2003). This 'Machiavellian' interpretation of Cicero's appeal to natural law is only reinforced if placed in the context of Cicero's call for a civil prince (princeps civitatis) to redeem the Republic in the later books of De republica.

But if Cicero can be said to move towards a 'Machiavellian' idea of the civil prince, Machiavelli, for his part, is taking the idea of the civil prince and of the state of exception in the opposite direction, away from the nobility in order to place it at the service of a plebeian politics that seeks to bring into the class conflict of the guild republic the perspective of those who stand outside of class society. This is the perspective voiced, but not ultimately enacted, by the famous speech of the Ciompo in the Florentine Histories: 'for all men, having had the same beginning, are equally ancient and have been made by nature in one mode. Strip all of us naked, you will see that we are all alike ... for only poverty and riches makes us unequal' (Machiavelli, 1988, III, Chapter 13). ${ }^{2}$ This perspective, this appeal to another equality of 'nature', is intended to bring back into light the primordial social conflict, which is not between those who have more and those who have less, but between those who represent class society, the populus, and those who seek a society without classes, the plebs. Machiavelli finds the paradigm of this original form of social conflict in the early Roman republic and its Struggle of Orders, and his interpretation transforms this paradigm into that 'Machiavellian moment', which is repeated throughout the revolutionary events of the modern epoch.

The Discourses on Livy defend the claim that 'all the laws that are made in favour of freedom arise from the disunion' between the plebs and the nobles (Machiavelli, 1996, I, Chapter 4). But what kind of conflict between these parts is productive of equal law? Rather than rehearse the long debates in the literature as to whether Machiavelli favours an elitist or a populist reconstruction of Roman social conflicts (Sullivan, 1996; Coby, 1999; Vatter, 2000; Fontana, 2003; Kapust, 2004; McCormick, 2011), I propose to consider Arnaldo Momigliano's theory of the Roman Struggle of Orders (Momigliano, 1984, 1989). This theory has the unique advantage of reconstructing the

254 (C) 2012 Macmillan Publishers Ltd. 1470-8914 Contemporary Political Theory Vol. 11, 3, 242-263 
conflict without presupposing an anachronistic construal of class divisions inherited from nineteenth-century Roman historiography. My hypothesis is that Momigliano's account captures a previously hidden aspect of the Struggle of Orders, which may also have been what attracted Machiavelli's attention to this form of social conflict.

Momigliano argues that archaic Roman society had a tripartite social organization composed by the patres (fathers) or heads of clans, who have exclusive access to authority (auctoritas) and occupy all religious functions during the monarchy, along with the so-called conscripti, who form part of the senate but lack the authority of the patres, and lastly, their clients. In its original meaning, the populus refers to the army of the king, which was composed by the patres, the conscripti and their clients. In this monarchical period of Roman history, there is no such thing as a 'class' of plebs that is opposed to the patricians. To think of the plebs as a class characterized by economic exploitation and desirous of the redistribution of riches, as the term gets employed in nineteenth- and twentieth-century sociology, is precisely to engage in the mistake of inventing what Momigliano calls a 'metaphysics' of the plebs. Strictly speaking, only the populus can be said to exhibit a class composition: the 'people' is composed of classes or ranks (classis) of citizens who together form the army, and who elect their commanders and approve of the laws put forward by the Senate through the Centuriate or Army assembly. On Momigliano's account, the plebs is not part of the ranks of the army, in the sense that they are not constituted parts of the populus. Plebs are said to be infra classem, they fall outside of the class division of Roman archaic society. They are, to employ Rancière's expression, a part with no participation in government.

The fact that the plebs is not a class or a rank turns out to be essential to understand the nature of its conflict with the populus: it explains why the plebs, when they do organize themselves politically, manifest their activity in the form of a constituent power, establishing a separate legislative assembly, an assembly of the plebs, that stood in opposition during the entire Struggle of Orders to the assembly of the army or populus. It was only with the gradual recognition of the decisions of the plebeian assembly (plebiscites) as having the 'force' of the patrician laws, that the plebs becomes integrated into the Roman populus. The important theoretical point is that the plebeian opposition to the authority of the 'fathers' and patricians takes on a political or constitutional form, rather than a military form, which would have generated into a civil war (a war that the plebs could not have won, because they lacked weapons and an army of their own) precisely in virtue of the plebs not being part of the army of the 'fathers', that is, in virtue of their not participating in the rule of the populus. The fundamental connection between no-rule and rule of law that Lefort unsuccessfully sought is to be found here. The plebs fought in the army, during 
the early Republic, only in times of emergency. It was precisely during one of these emergencies that they seceded to the Aventine and went on a 'general strike', refusing to join the 'fathers' in the defence of Rome until they agreed to recognize plebeians with an equal power to make law (but not an equal right to rule).

The plebeian general strike rejects the appeal to 'common utility' and the 'consensus of the law' that Cicero invokes as definitive of the populus, and that late medieval interpreters of Roman imperial law would employ to construct the sovereignty of the state and the doctrine of the state of exception that is peculiar to it. For Machiavelli, equal law ('the laws of freedom') is generated only from a plebeian state of exception. This exception of the plebs to the laws of the populus lies at the origin of the very idea of a separation of powers in a state, which is the fundamental principle of Roman and modern republican or neo-Roman constitutionalism. Such a separation of powers is not a way to unite the state, not a populist inclusion of the 'partiality' of the plebs that leads to the 'universality of the populus', to employ Laclau's terms, but is clearly a way to resist the legal and religious hegemony exerted by the populus and its militarized orders. Equal law is possible thanks to a form of dissent and conflict that takes place within and through the law itself; it is not the reflection of a consensus between classes. By developing a new form of negative power, the power to veto all commands of government magistrates (ius intercessionis) and the power to come to the aid of any member of the plebs if prosecuted by a patrician magistrate (ius auxili), and by founding a counter-religion of their own, centred around the temple of Ceres (which is related to the Greek goddess Demeter and the cult of Dionysus, the god of free men) in opposition to the patrician temple of Jupiter, the plebeian constitution acts as a counter-state within the state. Plebeian politics understands the constitution, and its division of powers, as that which makes possible a political life that lies 'beyond' the rule of the state and which places the achievement of equal law above the achievement of unitary order.

Momigliano writes that the general strike of the plebs, which opposed the 'justice of the patrician orders', nevertheless received 'the consecration of the gods' (Momigliano, 1989, p. 219). In his interpretations of Roman legal institutions, Agamben establishes an internal relation between the sacredness of the plebeian tribunes and the sovereign state of exception (Agamben, 1998; Agamben, 2000, 2003). Momigliano's notion of the 'sacredness' of the plebeian constituent power helps to offset Agamben's interpretation of the homo sacer as the seal of sovereignty because it indicates that plebeian sacrality, in the archaic Roman context, is an attribute of the plebeian state of exception and not of the senatorial state of exception. When the Roman plebs seceded from the Roman monarchical social order and retired to the Aventine Hill, they issued a judgement that whoever attacked their representatives (the tribunes) 
was liable to be killed, without the killer thereby committing a homicide, but equally without there having occurred a sacrifice (of innocent life to worship the gods). This sanction to kill is called sacratio; he who can be killed in this way is the homo sacer. It is likely that Momigliano's expression of a 'consecration of the gods' refers to this legal-political context.

Agamben argues that the practice of sacratio is characteristic of sovereignty because it places the banned individuals outside of both human and divine laws, so that they may be killed with impunity (Agamben, 1998, p. 82). But if the practice of sacratio originates from a plebs that has broken away from the populus or political society organized around the 'fathers' and is thus, technically speaking, completely lacking in legitimacy to issue laws of any kind, this would explain why their law-making comes from a (non)place that lies outside of both the civil and the religious laws of the populus. Whatever the plebs deemed to be a 'crime' against their desire for equal law could not be punished in virtue of being a transgression of either civil or religious laws. In other words, it is plausible that the plebeian practice of sacratio originates in a situation where what needs to be protected and what needs to be killed is the opposite of what Agamben suggests: the homo sacer, the enemy of the seceded people, was ultimately the Roman king turned tyrant and whoever represents its interests, and the sacratio would appear to be one of the first instances of what the Western political tradition has since called the right to revolution or the right to rebellion. In short, it would be the earliest figure of the republican justification of regicide. The state of exception that is both real and revolutionary is the one that bans sovereignty from the political life in the name of equal law. The plebeian 'laws of freedom' therefore emerge in a situation of exception to the order of the state such as to give place to a creation of equal law. The sovereign state of exception, on the contrary, takes exception to equal law in the name of establishing the order of the state.

\section{Conclusion: Democracy as the Kratos of Law}

Momigliano recounts the legend (Livy III, Chapter 31, Section, 8) that representatives of the Roman plebs travelled to Athens in order to learn from the demos about the practice of making laws (as they did not want to imitate the patrician legislation). Did the plebs want to bring back to Rome the isonomia (popular sovereignty) of their Athenian counterparts (Ostwald, 1989; Raaflaub et al, 2007)? But, if so, why did they then press for aequum ius (equal freedom to determine law)? After all, this equal access to law, though perhaps a Latin 'translation' of Greek isonomia (equal access to rule), is certainly not synonymous with it, because 'the notion of res publica postulates for every citizen a fair share in the common weal; it postulates the participation of the people in state affairs; it 
postulates that the government should be for the people; but it does not necessarily imply the principle of government by the people' (Wirszubski, 1950, p. 14). What did the plebs really bring back from Athens, if not the desire for hegemony? How can one participate in the 'common weal' without ruling over others?

Part of the answer can be inferred if one works backwards from Cicero's defence of the patrician state of exception, through the appeal to natural law, which rests upon an interpretation of the Roman republic according to the formula: 'leisure with dignity' otium cum dignitate (Cicero, Pro Sestio 98). According to this formula, the republic should provide the plebeians with peace and order (otium) and leave the 'dignity' of holding political office to the nobler ranks of society. The attribution of 'leisure' (otium) to the plebs is not an attempt to deprive them of access to offices, to the exercise of constituted power, as much as it is an attempt to rob them of the occasion to exercise their constituent power. Machiavelli's scathing critique in Discourses on Livy II, Chapter 2 of the ozio (leisure, laziness) that prevents people from living politically is a refutation of Cicero's understanding of the republic, for Machiavelli identifies the origins of the people's withdrawal from a life of action not only in Christianity's unworldliness, but also in the imperial expansion of the Roman republic that brought it to its end with Caesar. Perhaps what the plebeians were looking for in Athens was a way to participate in the political life of the people that would negate the 'peace and order' (later 'bread and circuses') offered them by the nobility, yet without thereby forcing them to take the place of the nobility and exercise in turn their kind of authority and rule (auctoritas and imperium).

If this is plausible, then one can say that in Athens the Roman plebs could have learned one of the original meanings of demokratia, according to which the demos was never considered a constituted part of the polis. The demos sought to participate in political life exclusively on the basis of the energy and potential (kratos) it displays for creating legal institutions, that is, in virtue of what today is called constituent power, and not in virtue of its capacity to govern or 'steer' the ship of state (Ober, 2008). According to Ober, the demos named this power of law-making with the term kratos in order to distinguish it from the name given to the power held by the constituted parts of the polis, namely the power to govern (archein), a power that characterizes monarchies and oligarchies. In other words, the Roman plebs could have learned that Athenian democracy was never intended to be a form of government or regime in which a people, as a constituted part of the city, has the authority to rule. On the contrary, democracy exists only in that regime in which the power of ruling, archein, can be negated by the power of legislation, the kratos, of those who have no part in the order of the populus and its sovereign authority (Rancière, 1995b; Chambers, 2010). In this way, democracy may regain its 'anarchic title', which Rancière has lately, and rightly, recognized as the crucial feature of any authentic democracy: "the only remaining title [outside of class society] is the 
anarchic title, the title specific to those who have no more title for governing than they have for being governed. This is what of all things democracy means. Democracy is not a type of constitution, nor a form of society ... . It is simply the power peculiar to those who have no more entitlements to govern than to submit' (Rancière, 2009, p. 46).

The Roman plebs understood that their constituent power to make equal law was the only safeguard they had against the power and authority of government: the limit to government set by such constituent activity was the only condition on which a true republic could be established. This power to make law belongs to the plebs in so far as it maintains itself as that part which does not participate in rule, as long as it safeguards the distinction between the law of the plebs and the order of the populus. This reading of plebeian politics resolves the problem I indicated at the start with Lefort, who had to drop the very idea of a classless society because he was unable to think such a society otherwise than under the figure of the unity of a 'totalitarian' People. On the reading proposed here, instead, the plebs designates that open and fluctuating association of those who want no part of class society. Plebeian politics is a 'state of exception', but one in which 'exception' is taken to the rank ordering of the populus (whose purpose is always that of turning the 'common weal' into a military and a financial reserve) and where 'state' refers to the status of the plebs as having a 'natural' right to equal freedom.

The quarrel between republicanism and populism can be resolved by holding onto the critical distinction between archein and kratos, between a struggle for the constituted power to govern over others, and a struggle for the constituent power not to be governed. To the extent that populist theory conceives of the equalization of populus and plebs by accepting the terms of the populus, that is, by conceiving the conflict between plebs and elites as a conflict between two antithetical classes, thus forgetting the two senses of the power of the people, its accounts of plebeian politics will always need to have recourse to the figure of the sovereign representative and to its state of exception. In the last instance, as I have shown in this article, this populist reason proves to be a variant of reason of state. If, conversely, the equalization of populus and plebs is understood in the constitutional terms established by the plebeian state of exception, as that rule of law which abolishes the distinction between those who rule and those who are ruled, then the plebeian cause may yet again meet with the favour of the gods and not simply with that of Cato.

\section{Acknowledgements}

Earlier versions of this article were read at the Machiavelli: Philosophy, Rhetoric, and History Conference, Yale University, 17-18 October 2008; at the 
International Conference, XVI Semana de Ética y Filosofía Política, Pasado, Presente y Futuro de la Democracia, Universidad de Murcia, 20-23 April 2009; and at the APSA Annual Meeting, Toronto, 3-6 September 2009. I thank the organizers and participants at these events for their productive critiques, as well as to Sam Chambers and the reviewers for their helpful suggestions. Work on this article was made possible by a Chilean state research Fondecyt grant n.1071087.

\section{Notes}

1 For my discussion of Augustine's conceptions of the people, I rely on the reading given in Heyking (1999), which brings out the crucial shift towards love as essential in the constitution of a people. See also Smith (2005). Heyking does not make use of Foucault's notion of pastoral power to understand Augustine's conception of the people.

2 For a recent treatment of the theme that argues that Machiavelli's ultimate sympathies extend to the Ciompo and its programme of social revolution rather than to Michele di Lando's programme, which ultimately does not overcome the limits of guild republicanism, see Winter (2009).

\section{References}

Abensour, M. (1994) Démocratie sauvage et principe d'anarchie. Les Cahiers de la philosophie (Lille) 18: 125-149.

Abensour, M. (2010) Democracy Against the State: Marx and the Machiavellian Movement. Oxford: Blackwell.

Agamben, G. (1993) Coming Community. Minneapolis, MN: University of Minnesota Press.

Agamben, G. (1998) Homo Sacer. Sovereign Power and Bare Life, Translated by D. Heller-Roazen. Stanford, CA: Stanford University Press.

Agamben, G. (2000) Means without End. Notes on Politics, Translated by V.B.C. Casarino. Minneapolis, MN: University of Minnesota Press.

Agamben, G. (2003) État d'exception. Paris: Seuil.

Agamben, G. (2007) Profanations. New York: Zone Books.

Althusser, L. (2001) Machiavelli and Us. London: Verso.

Arendt, H. (1990) On Revolution. New York: Penguin.

Augustine, S. (1984) The City of God, Translated by J. O'Meara. New York: Penguin.

Augustine, S. (2006) On Order, Translated by S. Borruso. South Bend, IN: St. Augustine's Press. Badiou, A. (2010) The Communist Hypothesis. London: Verso.

Barthas, J. (2010) Machiavelli in political thought from the age of revolutions to the present. In: J. Najemy (ed.), The Cambridge Companion to Machiavelli. New York: Cambridge University Press.

Bellamy, R. (2007) Political Constitutionalism. Cambridge: Cambridge University Press.

Berman, H. (1983) Law and Revolution. The Formation of the Western Legal Tradition. Cambridge: Harvard University Press.

Bock, G. (1990) Civil discord in Machiavellli's Istorie Fiorentine. In: G. Bock, Q. Skinner and M. Viroli (eds.), Machiavelli and Republicanism. Cambridge: Cambridge University Press. 
Chambers, S.A. (2010) Police and oligarchy. In: J.-P. Deranty (ed.), Jacques Rancière: Key Concepts. London: Acumen.

Coby, P.J. (1999) Machiavelli's Romans. Liberty and Greatness in the Discourses on Livy. Lanham, MD: Lexington Books.

Connolly, J. (2007) The State of Speech: Rhetoric and Political Thought in Ancient Rome. Princeton, NJ: Princeton University Press.

Cornell, T.J. (1995) The Beginnings of Rome. London: Routledge.

Flynn, B. (2006) The Philosophy of Claude Lefort. Interpreting the Political. Evanston, IL: Northwestern University Press.

Fontana, B. (2003) Sallust and the politics of Machiavelli. History of Political Thought 24(1): 86-108.

Foucault, M. (2000) Power. Essential Works of Foucault 1954-1984, J. Faubion (ed.), Vol. 3. New York: The New Press.

Foucault, M. (2004) Sécurité, Territoire, Population. Cours au Collège de France. 1977-1978. Paris: Gallimard Seuil.

Fubini, R. (1992) From social to political representation in renaissance Florence. In: K.R. Anthony Molho and J. Emlen (eds.), City States in Classical Antiquity and Medieval Italy. Ann Arbor, MI: University of Michigan Press.

Gregory, E. (2008) Politics and the Order of Love: An Augustinian Ethic of Democratic Citizenship. Chicago, IL: University of Chicago Press.

Grossi, P. (2004) L'ordine giuridico medievale. Bari, Italy: Laterza.

Hankins, J. (2010) Exclusivist republicanism and the non-monarchical republic. Political Theory 38(4): 452-482.

Heyking, J.v. (1999) A headless body politic? Augustine's understanding of a populus and its representation. History of Political Thought 20(4): 499-567.

Heykind, J.v. (2001) Augustine and Politics as Longing in the World. Columbia, MO: University of Missouri Press.

Kalyvas, A. (2000) Hegemonic sovereignty: Carl Schmitt, Antonio Gramsci and the constituent prince. Journal of Political Ideologies 5(3): 343-376.

Kalyvas, A. (2009) Democracy and the Politics of the Extraordinary: Max Weber, Carl Schmitt and Hannah Arendt. New York: Cambridge University Press.

Kapust, D. (2004) Skinner, Pettit and Livy: The conflict of the orders and the ambiguity of republican liberty. History of Political Thought 25(3): 377-401.

Laclau, E. (2005) On Populist Reason. London: Verso.

Laclau, E. and Mouffe, C. (2001) Hegemony and Socialist Strategy: Towards a Radical Democratic Politics. London: Verso.

Lefort, C. (1978) Sur une colonne absente. Écrits autour de Merleau-Ponty. Paris: Gallimard.

Lefort, C. (1979) Éléments d'une critique de la bureaucratie. Paris: Gallimard.

Lefort, C. (1986a) Le travail de l'oeuvre Machiavel. Paris: Gallimard.

Lefort, C. (1986b) The Political Forms of Modern Society. Cambridge, MA: MIT Press.

Lefort, C. (1992) Écrire. À l'épreuve du politique. Paris: Calmann-Lévy.

Linera, Á.G. (2009) La potencia plebeya. La Paz: CLACSO.

Machiavelli, N. (1988) Florentine Histories, Translated by L.F. Banfield and H.C. Mansfield. Princeton, NJ: Princeton University Press.

Machiavelli, N. (1996) Discourses on Livy, Translated by N. Tarcov and H. Mansfield. Chicago, IL: University of Chicago Press.

Machiavelli, N. (1998) The Prince, Translated by H.C. Mansfield. Chicago, IL: University of Chicago Press.

Magdelain, A. (1990) Jus Imperium Auctoritas. Études de droit romain. Rome: École Francaise de Rome.

(C) 2012 Macmillan Publishers Ltd. 1470-8914 Contemporary Political Theory Vol. 11, 3, 242-263 261 
Marchart, O. (2007) Post-Foundational Political Thought: Political Difference in Nancy, Lefort, Badiou and Laclau. Edinburgh, UK: Edinburgh University Press.

Markell, P. (2006) The rule of the people: Arendt, Arche, and democracy. American Political Science Review 100(1): 1-14.

May, T. (2010) Contemporary Political Movements and the Thought of Jacques Rancière: Equality in Action. Edinburgh, UK: Edinburgh University Press.

McCormick, J. (2006) Contain the wealthy and patrol the magistrates: Restoring elite accountability to popular government. American Political Science Review 100(2): 147-163.

McCormick, J.P. (2007) Machiavelli's political trials and the 'free way of life'. Political Theory 35(4): 385-411.

McCormick, J.P. (2011) Machiavellian Democracy. New York: Cambridge University Press.

Mitchell, R.E. (1990) Patricians and Plebeians. The Origin of the Roman State. Ithaca, NY: Cornell University Press.

Momigliano, A. (ed.), (1984) Prolegomena a ogni futura metafisica sulla plebe romana. In: Sui fondamenti della storia antica. Turin, Italy: Einaudi.

Momigliano, A. (ed.), (1989) Osservazioni sulla distinzione fra patrizi e plebei. In: Roma Arcaica. Florence, Italy: Sansoni.

Najemy, J. (2000) Civic humanism and Florentine politics. In: J. Hankins (ed.), Renaissance Civic Humanism. Cambridge: Cambridge University Press.

Nasstrom, S. (2007) The legitimacy of the people. Political Theory 35(5): 624-658.

Nederman, C.J. (2004) Rhetoric, reason and republic - Republicanisms: Ancient, medieval, and modern. In: J. Hankins (ed.), Renaissance Civic Humanism. Reappraisals and Reflections. Cambridge: Cambridge University Press.

Nederman, C.J. (2009) Lineages of European Political Thought: Explorations along the Medieval/ Modern Divide from John of Salisbury to Hegel. Washington DC: Catholic University of America Press.

Negri, A. (1999) Insurgencies: Constituent Power and the Modern State. Minneapolis, MN: University of Minnesota Press.

Ober, J. (2008) The original meaning of 'democracy': Capacity to do things, not majority rule. Constellations 15(1): 3-9.

O’Donnell, G. (2007) Dissonances: Democratic Critiques of Democracy. Notre Dame, IN: University of Notre Dame Press.

Ostwald, M. (1989) From Popular Sovereignty to the Sovereignty of Law: Law, Society and Politics in Fifth-century Athens. Berkeley, CA: University of California Press.

Pettit, P. (1997) Freedom and antipower. Ethics 106: 576-604.

Pettit, P. (2009a) Law and liberty. In: S. Besson and J.L. Martí (eds.), Law and Republicanism. Oxford: Oxford University Press.

Pettit, P. (2009b) The power of a democratic public. In: R. Gotoh and P. Dumouchel (eds.), Against Injustice: The New Economics of Amartya Sen. Cambridge: Cambridge University Press.

Post, G. (1964) Studies in Medieval Legal Thought: Public Law and the State 1100-1322. Princeton, NJ: Princeton University Press.

Raaflaub, K. (ed.), (2006) Social Struggles in Archaic Rome. New Perspectives on the Conflict of Orders. Oxford: Wiley-Blackwell.

Raaflaub, K., Ober, J. and Wallace, R. (eds.), (2007), Origins of Democracy in Ancient Greece. Berkeley, CA: University of California Press.

Rancière, J. (1995a) La Mésentente. Politique et Philosophie. Paris: Galilée.

Rancière, J. (1995b) On the Shores of Politics. London: Verso.

Rancière, J. (2009) Hatred of Democracy. London: Verso.

Rosanvallon, P. (2006) La contre-démocratie. La politique à l'age de la défiance. Paris: Éditions du Seuil.

262 (C) 2012 Macmillan Publishers Ltd. 1470-8914 Contemporary Political Theory Vol. 11, 3, 242-263 
Rubinstein, N. (2004) Studies in Italian History in the Middle Ages and the Renaissance. In: G. Ciappelli (ed.), Vol. 1. Rome: Edizioni di Storia e Letteratura.

Schmitt, C. (2008) Political Theology II. The Myth of the Closure of any Political Theology. Cambridge: Polity Press.

Sfez, G. (1998) Machiaveli, le prince sans qualités. Paris: Kimé.

Skinner, Q. (1978) The Foundations of Modern Political Thought. Vol. II. The Age of Reformation. Cambridge: Cambridge University Press.

Skinner, Q. (2002) Visions of Politics. Vol. 2. Renaissance Virtues. Cambridge: Cambridge University Press.

Smith, T.W. (2005) The glory and tragedy of politics. In: K. Hughes, J. Doody and K. Paffenroth (eds.), Augustine and Politics. Oxford: Lexington Books.

Sullivan, V. (1996) Machiavelli's Three Romes. De Kalb, IL: Northern Illinois University Press.

Vatter, M. (2000) Between Form and Event: Machiavelli's Theory of Political Freedom. Dordrecht, The Netherlands and Boston, MA: Kluwer Academic Publishers.

Vatter, M. (2005) Pettit and modern republican political thought. In: M. Williams and S. Macedo (eds.), NOMOS XLVI Political Exclusion and Domination. New York: New York University Press.

Vatter, M. (2007) Resistance and legality: Arendt and Negri on constituent power. In: T. Murphy and A.K. Mustapha (eds.), The Philosophy of Toni Negri, Vol. 2. London: Pluto Press.

Vatter, M. (2008) The idea of public reason and the reason of state. Schmitt and Rawls on the political. Political Theory 36(2): 239-271.

Villacañas Berlanga, J.L. (2010) The liberal roots of populism: A critique of Laclau. New Centennial Review 10(2): 151-182.

Voegelin, E. (1952) The New Science of Politics. Chicago, IL: University of Chicago Press.

Winter, Y. (2009) Anonymous violence: Machiavelli and the Ciompi uprising. Unpublished paper read at American Political Science Association Annual Meeting, 3-6 September, Toronto.

Wirszubski, C. (1950) Libertas as a Political Idea at Rome during the Late Republic and the Early Principate. Cambridge: Cambridge University Press.

Zancarini, J.-C. (2004) La révolte des Ciompi. Machiavel, ses sources et ses lecteurs. Cahiers philosophiques 97: 9-22. 